\title{
LECTURES BY FOREIGN EXPERTS AT THE FACULTY OF ARTS, MASARYK UNIVERSITY

\section{OTAKAR KIRSCH}

The development of museology as an independent and autonomous discipline is unimaginable without an intensive exchange of information between professionals in both national and international context. Previous calendar year provided Czech museology in this regard with an interesting possibility of comparison with ideological streams and results of topical foreign research. The Centre of Museology of the Department of Archaeology and Museology, Masaryk University and the UNESCO Chair of Museology and World Heritage, thanks to financial means obtained from the internal grant project titled Improvement of conditions for the activities of significant foreign academics at the Masaryk University, organised within the scope of the Special Topics of Museology course the $1^{\text {st }}$ and the $2^{\text {nd }}$ cycle of lectures by selected experts, which were targeted not only at students in museology and related disciplines, but have also addressed other interested non-professionals as well as members of the professional public.

During 2015/2016, a total of 15 lectures by nine foreign museologists have taken place at the Masaryk University. Most participants were traditionally represented by colleagues from Slovakia. Among them were representatives of museological centres in Bratislava (Pavol Tišliar, Luboš Kačírek) and Nitra (Silvia Eliašová) and of the professional committee for museum education at the Slovak Museum Association
(Dominik Hrdý). But among the host lecturers in Brno also were museologists from the USA (James Deutsch), Austria (Bernadette Biedermann), Poland (Dorota Folga-Januszewska) or Slovenia (Verena Vidrih Perko), and two representatives were sent by the traditional museological centre at Leicester (Cintia Velázquez-Marroni and Laura Crossley). This way it was possible to obtain a representative sample which did not involve only experts from the academic sphere, but also employees of museum institutions and state administration bodies, most of them representing younger and middle generation. Personal talks with individual guests and the proceedings of presentations revealed the inclination of presentday museology to several topics, mainly the problem of cultural heritage, museum pedagogy and psychology, or the analysis of historical and currently emerging forms, through which the people put into practice their museum relationship to the surrounding reality. Despite considerable differences between individual approaches it was possible to see the vast potential and the possibilities of museological discipline. These were still intensified by several lecturers posing provocative questions, which raised vivid interest and discussion in the audience. The readers can finally familiarize themselves with the content of some ideas and theses in the currently published issue of the Museologica Brunensia journal. The following issues, with regard to the autumn issue dedicated completely to the personality of deceased Zbyněk Zbyslav Stránský, should be published in 2017.

Very encouraging is that many interesting guests confirmed their participation in this and in the next year of the project. Among them are many recognised personalities of world museology. Brno thus should be visited by, for example, Jesús Pedro Lorente (Spain), Alexandra Bounia (Greece) or Darko Babić (Croatia). By organising this event, which is quite specific and unusual for the Czech milieu, the Centre of Museology and the UNESCO Chair of Museology and World Heritage continue the establishment of traditional contacts and forms of cooperation above all with foreign museological institutions. This is one of important ways of how to raise the professional level of the discipline and its society-wide prestige.

\section{OTAKAR KIRSCH}

Centre of Museology, Masaryk University, Brno 